\title{
BIOCHEMICAL IDENTIFICATION OF PHARMACOLOGICALLY AND FUNCTIONALLY DISTINCT GABA RECEPTORS IN RAT BRAIN ${ }^{1}$
}

\author{
M. BROWNER, J. W. FERKANY, ${ }^{2}$ AND S. J. ENNA ${ }^{3}$ \\ Departments of Pharmacology and of Neurobiology and Anatomy, The University of Texas Medical School at Houston, Houston, Texas 77025
}

\begin{abstract}
Receptor binding studies were undertaken in an attempt to identify and characterize pharmacologically and functionally distinct receptor sites for $\gamma$-aminobutyric acid (GABA) in rat brain. The results indicated that the potency of bicuculline, a GABA receptor antagonist, to displace membranebound $\left[{ }^{3} \mathrm{H}\right] \mathrm{GABA}$ varies significantly among different brain regions, with the greatest potency found in the cerebral cortex and midbrain. In addition, in the presence of $50 \mathrm{~mm}$ ammonium thiocyanate, the potency of bicuculline to displace specifically bound $\left[{ }^{3} \mathrm{H}\right]$ GABA was increased significantly, with the magnitude of this increase being greater in some brain areas than others. The biological relevance of this thiocyanate-induced shift in the potency of bicuculline to inhibit $\left[{ }^{3} \mathrm{H}\right] \mathrm{GABA}$ binding was indicated by the finding that ammonium thiocyanate also increased the potency of bicuculline to inhibit GABA-activated benzodiazepine receptor binding, a biochemical measure of GABA receptor function. Receptor site saturation analysis revealed that ammonium thiocyanate selectively abolished the high affinity GABA binding site without affecting either the low affinity component or GABA-activated benzodiazepine receptor binding. These findings provide further evidence for the existence of pharmacologically distinct GABA receptor sites, with some being more sensitive to the blocking action of bicuculline than others. Furthermore, the data provide direct evidence to support the hypothesis that only low affinity GABA receptor sites are linked to the benzodiazepine receptor, indicating that the kinetically different GABA binding sites are also functionally distinct. The discovery that ammonium thiocyanate selectively destroys high affinity GABA receptor binding may be useful for further defining the pharmacological, biochemical, and functional differences between GABA receptors in brain.
\end{abstract}

It has been estimated that $\gamma$-aminobutyric acid (GABA) is the neurotransmitter for up to $40 \%$ of the neurons in the mammalian central nervous system (Bloom and Iversen, 1971). In light of this ubiquity, it is somewhat surprising that, unlike the catecholamines and acetylcholine, there is, as yet, little direct evidence to support the existence of pharmacologically and functionally distinct subsets of synaptic receptor sites for this amino acid in brain (Enna, 1981a, b). Electrophysiological and biochemical experiments have indicated that there may be a class of bicuculline-insensitive GABA receptors (Curtis and Felix, 1971; Krnjevic, 1974; Bowery et al., 1980), but in the absence of pharmacological tools

\footnotetext{
' This work was supported in part by United States Public Health Service Grant NS-13803, Research Career Development Award NS00335 (S. J. E.), and Predoctoral Fellowship MH-07688 (J. W. F.).

${ }^{2}$ Present address: Departments of Neuroscience, Pharmacology, and Psychiatry, Johns Hopkins University School of Medicine, 725 North Wolfe Street, Baltimore, MD 21205.

${ }^{3}$ To whom correspondence and reprint requests should be addressed at Departments of Pharmacology and of Neurobiology and Anatomy, The University of Texas Medical School at Houston, P. O. Box 20708, Houston, TX 77025.
}

to characterize these sites further, it is impossible to define their biological significance. In addition, receptor ligand binding studies have identified at least two kinetically distinct binding sites for GABA in brain tissue, although their pharmacology appears to be quite similar if not identical (Enna and Snyder, 1977).

More recently, reports have indicated that GABA receptors are functionally linked to benzodiazepine binding sites in brain (Tallman et al., 1978; Maggi et al., 1980). These experiments have revealed that, in vitro, activation of GABA receptors induces a shift in the affinity of the benzodiazepine binding site, with increasing concentrations of GABA inducing an increase in the amount of bound radiolabeled benzodiazepine. As a result of these findings, a number of laboratories have explored the relationship between benzodiazepine and GABA receptors. Both biochemical and autoradiographic studies suggest that, in fact, not all GABA receptors are linked to the benzodiazepine binding site (Young and Kuhar, 1979; Palacios et al., 1979), indicating some degree of functional specificity for GABA receptors.

In the present study, experiments were undertaken to characterize further the biochemical, pharmacological, 
and functional properties of GABA receptors in various regions of the rat brain in an attempt to identify GABA receptor subtypes. The results indicate that it is possible to differentiate classes of GABA receptor binding sites on the basis of their sensitivity to ammonium thiocyanate, a chaotropic agent. These data provide direct evidence that the benzodiazepine receptor is affiliated with only one type of GABA receptor, the lower affinity binding site, providing further proof that the kinetically distinct GABA receptor sites may differ also with regard to their pharmacological and functional properties.

\section{Materials and Methods}

Male Sprague-Dawley rats (125 to $150 \mathrm{gm}$ ) were used in all experiments. The animals were killed by decapitation and the brains were removed rapidly, dissected, and stored at $-20^{\circ} \mathrm{C}$ until assayed.

GABA receptor binding to brain homogenates was analyzed using the method of Enna and Synder (1977). Briefly, the frozen tissue was homogenized in $70 \mathrm{vol}$ of $0.05 \mathrm{M}$ Tris-citrate $\left(\mathrm{pH} 7.1\right.$ at $\left.4^{\circ} \mathrm{C}\right)$ and then centrifuged at $48,000 \times g$ for $10 \mathrm{~min}$ at $4^{\circ} \mathrm{C}$. The membrane pellet was resuspended in buffer to a concentration of $1 \mathrm{mg}$ of protein $/ \mathrm{ml}$ and sufficient Triton X-100 was added to yield a $0.05 \%(\mathrm{v} / \mathrm{v})$ concentration of detergent. This suspension was incubated at $37^{\circ} \mathrm{C}$ for $20 \mathrm{~min}$ and then centrifuged as above. The resultant pellet was resuspended in buffer and centrifuged two more times prior to the preparation of a final aqueous suspension of the membranes, which contained 0.5 to $1 \mathrm{mg}$ of protein $/ \mathrm{ml}$. For the receptor binding assay, $1 \mathrm{ml}$ portions of this membrane suspension were added to tubes containing 1 $\mathrm{ml}$ of 0.1 M buffer plus $\left[{ }^{3} \mathrm{H}\right]-\gamma$-aminobutyric acid $\left.\left({ }^{3} \mathrm{H}\right] \mathrm{GABA} ; 57 \mathrm{Ci} / \mathrm{mmol}\right)$ in the presence and absence of various concentrations of unlabeled GABA or bicuculline, a GABA receptor antagonist. The mixture was incubated, the reaction was terminated by centrifugation, and the tissue was analyzed as previously described (Enna and Snyder, 1977). Total specific receptor binding was defined as the amount of $\left[{ }^{3} \mathrm{H}\right] \mathrm{GABA}$ displaced by $10^{-3}$ M unlabeled GABA. The concentration of $\left[{ }^{3} \mathrm{H}\right]-$ GABA in the incubation medium was $4 \mathrm{nM}$.

In some experiments, receptor binding was assayed in the presence of $50 \mathrm{~mm}$ ammonium thiocyanate (SCN). In this case, the buffer in the assay tubes contained 100 mM SCN prior to the addition of tissue homogenate.

GABA receptor site saturation studies were conducted by analyzing the amount of specifically bound $\left[{ }^{3} \mathrm{H}\right] \mathrm{GABA}$ after incubating the tissue with a fixed concentration of isotope $(4 \mathrm{nM})$ in the presence of increasing concentrations of unlabeled GABA ( 1 to $500 \mathrm{nM}$ ). The binding site affinity $\left(K_{d}\right)$ and concentration $\left(B_{\max }\right)$ were determined by Scatchard analysis of the displacement data.

Basal and GABA-activated $\left[{ }^{3} \mathrm{H}\right]$ diazepam $(76.8 \mathrm{Ci} /$ mmol) binding were analyzed using a previously published procedure (Maggi et al., 1980). The tissue was treated with Triton X-100 as above and resuspended and centrifuged five times with the same buffer used for the GABA receptor assay.

To analyze benzodiazepine receptor binding, the tissue was incubated with $0.3 \mathrm{nM}\left[{ }^{3} \mathrm{H}\right]$ diazepam in the presence and absence of $5 \mu \mathrm{M}$ unlabeled diazepam (blank). Specific binding was defined as the amount of isotope displaced by the unlabeled ligand. GABA-activated binding was analyzed by conducting the $\left[{ }^{3} \mathrm{H}\right]$ diazepam binding assay in the presence of $100 \mu \mathrm{M}$ unlabeled GABA. To determine the potency of GABA to activate benzodiazepine binding, $\left[{ }^{3} \mathrm{H}\right]$ diazepam binding was quantified in the presence of 0.1 to $100 \mu \mathrm{M}$ concentrations of unlabeled GABA. The maximal $\left[{ }^{3} \mathrm{H}\right]$ diazepam binding above basal was set at $100 \%$ and the concentration of unlabeled GABA necessary to increase radioligand binding to $50 \%$ of this value $\left(\mathrm{EC}_{50}\right)$ was determined by log-probit analysis. In some experiments, basal and GABA-activated $\left[{ }^{3} \mathrm{H}\right]$ diazepam binding assays were conducted in the presence of $50 \mathrm{~mm}$ SCN.

Levels of significance between means were determined using a two-tailed Student's $t$ test. Values were considered to be significantly different if $p<0.05$.

$\left[{ }^{3} \mathrm{H}\right]$ GABA was purchased from Amersham Corp. and $\left[{ }^{3} \mathrm{H}\right]$ diazepam from New England Nuclear. Ammonium thiocyanate was obtained from Fisher Scientific Co. and bicuculline from Calbiochem. All other reagents and supplies were obtained from commercial sources.

\section{Results}

Regional variation in the potency of bicuculline to displace $\left[{ }^{3} H\right] G A B A$ and the effect of ammonium thiocyanate. Previous work had indicated that $50 \mathrm{~mm}$ ammonium thiocyanate and other chaotropic agents increase the potency of bicuculline to displace $\left[{ }^{3} \mathrm{H}\right] \mathrm{GABA}$ from rat brain membranes without appreciably altering the affinity of the receptor for GABA itself (Enna and Snyder, 1977). It is noteworthy, however, that in this earlier study, the brain membranes had not been treated with Triton X-100. To determine whether there was any regional specificity for this phenomenon with Tritontreated tissue, the potency of bicuculline to inhibit $\left[{ }^{3} \mathrm{H}\right]$ GABA binding in the presence of $50 \mathrm{~mm}$ ammonium thiocyanate was examined in various brain regions (Table I). The results indicated that ammonium thiocyanate causes markedly different shifts in the potency of bicuculline in the brain regions studied, with the potency of bicuculline increasing almost 100 -fold in the midbrain but only 10 -fold in the cerebellum. Intermediate shifts

\section{TABLE I}

Effect of $50 \mathrm{mM}$ ammonium thiocyanate on the potency of bicuculline to displace $\left[^{3} H\right] G A B A$ binding in various regions of the rat brain

The concentration of bicuculline necessary to inhibit $50 \%$ of the specifically bound $\left[{ }^{3} \mathrm{H}\right] \mathrm{GABA}\left(\mathrm{IC}_{50}\right)$ was determined in various rat brain regions in the presence and absence of $50 \mathrm{~mm}$ ammonium thiocyanate (SCN). Values are the means \pm SEM of four or five separate experiments, each performed in triplicate.

\begin{tabular}{|c|c|c|c|}
\hline \multirow{2}{*}{$\begin{array}{l}\text { Brain } \\
\text { Region }\end{array}$} & \multicolumn{2}{|c|}{ Bicuculline $I C_{(x)}$} & \multirow{2}{*}{$\begin{array}{c}\mathrm{IC}_{\mathrm{s}(0)} \text { Ratio } \\
(-\mathrm{SCN} /+\mathrm{SCN})\end{array}$} \\
\hline & $-\mathrm{SCN}$ & $+\mathrm{SCN}$ & \\
\hline \multicolumn{4}{|c|}{$\mu M$} \\
\hline Midbrain & $0.72 \pm 0.22$ & $0.007 \pm 0.002^{a}$ & 97 \\
\hline Cerebral cortex & $0.75 \pm 0.22$ & $0.012 \pm 0.003^{\circ}$ & 63 \\
\hline Corpus striatum & $2.27 \pm 0.64^{b}$ & $0.09 \pm 0.03^{a}$ & 25 \\
\hline Cerebellum & $3.54 \pm 0.72^{b}$ & $0.26 \pm 0.06^{a}$ & 14 \\
\hline
\end{tabular}

${ }^{a} p<0.01$ compared to value obtained in the absence of SCN.

${ }^{b} p<0.05$ compared to midbrain. 
were noted in the cerebral cortex (63-fold) and corpus striatum (25-fold) (Table I). Interestingly, the potency of bicuculline to displace receptor-bound $\left[{ }^{3} \mathrm{H}\right] \mathrm{GABA}$ differs among the various brain regions even in the absence of ammonium thiocyanate, with the $\mathrm{IC}_{50}$ for bicuculline in the corpus striatum and cerebellum being over 3 times greater than that found in the midbrain and cerebral cortex. This suggests that the cortical and midbrain GABA receptors have a greater affinity for bicuculline than the receptors labeled in the corpus striatum and cerebellum (Table I). Furthermore, the differences between these brain regions is magnified in the presence of ammonium thiocyanate. Thus, bicuculline was 10 - to 20 fold weaker in the corpus striatum and cerebellum than in the midbrain and cerebral cortex even in the presence of the chaotropic agent.

Influence of ammonium thiocyanate on GABA receptor function. To determine whether the ammonium thiocyanate-induced increase in the potency of bicuculline had any functional significance, the ability of this alkaloid to inhibit GABA-activated benzodiazepine receptor binding was examined in the presence and absence of the salt (Table II). As seen with the GABA receptor binding assay, bicuculline was significantly weaker in inhibiting GABA-activated $\left[{ }^{3} \mathrm{H}\right]$ diazepam binding in the cerebellum as compared to the cerebral cortex. Similarly, when the assay was performed in the presence of ammonium thiocyanate, the potency of bicuculline to inhibit GABAactivated benzodiazepine receptor binding was increased significantly in both brain regions, being enhanced about 30 -fold in the cerebral cortex and about 10 -fold in cerebellar membranes (Table II). Ammonium thiocyanate also increased the difference in the potency of bicuculline in the two brain regions to inhibit the GABA receptormediated change in $\left[{ }^{3} \mathrm{H}\right]$ diazepam binding. Thus, in the absence of the salt, the $\mathrm{IC}_{50}$ for bicuculline was some 2fold greater (lower affinity) in the cerebellum than in the cerebral cortex, whereas in the presence of thiocyanate, the difference was almost 10 -fold (Table II).

The influence of ammonium thiocyanate on GABA and benzodiazepine receptor binding. In addition to

TABLE II

Effect of $50 \mathrm{mM}$ ammonium thiocyanate on the potency of bicuculline to inhibit GABA-activated $\left[{ }^{3} H\right]$ diazepam binding in rat brain cerebral cortex and cerebellum

The concentration of bicuculline necessary to inhibit by $50 \%\left(\mathrm{IC}_{50}\right)$ the activation of $\left[{ }^{3} \mathrm{H}\right]$ diazepam binding by GABA $(100 \mu \mathrm{M})$ was determined in various areas of the rat brain in the presence and absence of $50 \mathrm{~mm}$ ammonium thiocyanate (SCN). Values are the means \pm SEM of five separate experiments, each performed in triplicate.

\begin{tabular}{ccc}
\hline \multirow{2}{*}{ Brain Region } & \multicolumn{2}{c}{ Bicuculline $\mathrm{IC}_{50}$} \\
\cline { 2 - 3 } & $-\mathrm{SCN}$ & $+\mathrm{SCN}$ \\
\hline Cerebral cortex & $7 \pm 1$ & $\mu \mathrm{M}$ \\
Cerebellum & $(5)$ & $0.19 \pm 0.02^{a}$ \\
& $12 \pm 2^{b}$ & $(5)$ \\
& $(5)$ & $(5)$ \\
\hline
\end{tabular}

${ }^{a} p<0.005$ with respect to the corresponding value obtained in the absence of SCN and to the value obtained in the other brain region in the presence of SCN.

${ }^{b} p<0.05$ compared to cortex. altering the potency of bicuculline to displace $\left[{ }^{3} \mathrm{H}\right] \mathrm{GABA}$ binding, $50 \mathrm{~mm}$ ammonium thiocyanate significantly reduced the amount of GABA bound to rat brain membranes (Table III). When the assay medium contained the salt, specifically bound $\left[{ }^{3} \mathrm{H}\right] \mathrm{GABA}$ was reduced by $34 \%$ in the cerebral cortex and over $25 \%$ in the cerebellum. Nonspecific binding was not significantly influenced by this treatment. In addition, neither basal $\left[{ }^{3} \mathrm{H}\right]$ diazepam binding nor GABA-activated $\left[{ }^{3} \mathrm{H}\right]$ diazepam binding was altered significantly in the presence of ammonium thiocyanate (Table III).

To determine the reason for the reduction in specifically bound $\left[{ }^{3} \mathrm{H}\right] \mathrm{GABA}$ binding, GABA receptor saturation analysis was performed in the presence and absence of the salt (Table IV). In the absence of ammonium thiocyanate, a two-component saturation curve was detected, indicating the presence of high affinity $\left(K_{d}=33\right.$ $\mathrm{nM})$ and low affinity $\left(K_{d}=110 \mathrm{nM}\right)$ binding sites for this amino acid. However, in the presence of $50 \mathrm{~mm}$ ammonium thiocyanate, only a single $\left[{ }^{3} \mathrm{H}\right] \mathrm{GABA}$ receptor bind-

TABLE III

Effect of $50 \mathrm{mM}$ ammonium thiocyanate on the specific binding of $\left[{ }^{3} \mathrm{H}\right] \mathrm{GABA},\left[{ }^{3} \mathrm{H}\right]$ diazepam, and GABA-activated $\left[{ }^{3} \mathrm{H}\right]$ diazepam binding in rat brain cerebral cortex and cerebellum

$\left[{ }^{3} \mathrm{H}\right] \mathrm{GABA},\left[{ }^{3} \mathrm{H}\right]$ diazepam, and $100 \mu \mathrm{M}$ GABA-activated $\left[{ }^{3} \mathrm{H}\right]$ diazepam binding were analyzed in membranes derived from rat brain cerebral cortex and cerebellum in the presence and absence of $50 \mathrm{~mm}$ ammonium thiocyanate (SCN). Values are the means of five separate determinations, each performed in triplicate.

\begin{tabular}{llc}
\hline \multicolumn{1}{c}{${ }^{\text {sH Ligand }}$} & Brain Region & $\begin{array}{c}\text { Specific Binding in the } \\
\text { Presence of SCN (\% of } \\
\text { Control) }\end{array}$ \\
\hline GABA & $\begin{array}{l}\text { Cerebral cortex } \\
\text { Cerebellum }\end{array}$ & $66^{a}$ \\
& Cerebral cortex & $74^{\prime \prime}$ \\
Diazepam & Cerebellum & 93 \\
& Cerebral cortex & 91 \\
GABA-activated di- & Cerebellum & 100 \\
azepam & & 92 \\
\hline
\end{tabular}

${ }^{a} p<0.05$ compared to control.

TABLE IV

Effect of $50 \mathrm{mM}$ ammonium thiocyanate on the characteristics of $\left.l^{3} \mathrm{H}\right] G A B A$ receptor binding in rat cerebellum

GABA receptor binding site saturation analysis was conducted in rat cerebellar membranes, in the presence and absence of $50 \mathrm{~mm}$ ammonium thiocyanate (SCN), after prior treatment with Triton X-100. For the analysis, specific $\left[{ }^{3} \mathrm{H}\right] \mathrm{GABA}$ binding was determined using a fixed concentration of isotope $(3.9 \mathrm{nM})$ and increasing concentrations of unlabeled GABA ( 1 to $500 \mathrm{~nm}$ ). High and low binding site affinities $\left(K_{d}\right)$ and concentrations $\left(B_{\max }\right)$ were estimated by Scatchard analysis. Values are the means \pm SEM of five separate determinations, each performed in triplicate.

\begin{tabular}{|c|c|c|c|c|}
\hline \multirow{3}{*}{ Condition } & \multicolumn{4}{|c|}{$\left[{ }^{3} \mathrm{H}\right]$ GABA Receptor Binding } \\
\hline & \multicolumn{2}{|c|}{$K_{d}$} & \multicolumn{2}{|c|}{$B_{\max }$} \\
\hline & High & Low & High & Low \\
\hline & \multicolumn{2}{|c|}{$n M$} & \multicolumn{2}{|c|}{$\mathrm{pmol} / \mathrm{mg}$ protein } \\
\hline $\begin{array}{l}-\mathrm{SCN} \\
+\mathrm{SCN}\end{array}$ & $\begin{array}{c}33 \pm 6 \\
\mathrm{ND}^{a}\end{array}$ & $\begin{array}{r}110 \pm 9 \\
96 \pm 9\end{array}$ & $\begin{array}{c}1.4 \pm 0.3 \\
\mathrm{ND}^{a}\end{array}$ & $\begin{array}{l}3.3 \pm 0.4 \\
2.8 \pm 0.4\end{array}$ \\
\hline
\end{tabular}

${ }^{a} \mathrm{ND}$, not detectable. 
ing site was detected, with an affinity (96 nM) and concentration $(2.8 \mathrm{pmol} / \mathrm{mg}$ of protein) virtually identical to that observed for the low affinity site noted in the absence of ammonium thiocyanate (Table IV). This finding indicated that ammonium thiocyanate can selectively abolish the high affinity GABA receptor binding site.

Potency of GABA to activate benzodiazepine receptor binding in the presence and absence of ammonium thiocyanate. While ammonium thiocyanate did not alter the increase in $\left[{ }^{3} \mathrm{H}\right]$ diazepam binding induced by a saturating concentration of GABA (Table III), it is conceivable that this treatment affected the potency of GABA to initiate this response. To test this, $\left[{ }^{3} \mathrm{H}\right]$ diazepam binding was determined in the presence of various concentrations of unlabeled GABA, with and without ammonium thiocyanate (Table V). Incubation with $50 \mathrm{~mm}$ ammonium thiocyanate did not alter the potency of GABA to activate benzodiazepine binding in either the cerebral cortex or cerebellum, suggesting that the activation phenomenon is unaffected by treatment with this chaotropic agent.

\section{Discussion}

The results of the present investigation lend further evidence to support the existence of multiple GABA binding sites. These data indicate that not only are there different classes of GABA receptor binding sites based on differing affinities for bicuculline, but also that the high and low affinity GABA receptor sites differ with regard to function. This was suggested by the results obtained with ammonium thiocyanate which indicated that the low, but not the high, affinity GABA receptor binding site is coupled to the benzodiazepine receptor site.

The finding that bicuculline is significantly more potent in displacing $\left[{ }^{3} \mathrm{H}\right] \mathrm{GABA}$ from midbrain and cerebral cortical tissue than from corpus striatum and cerebellum was somewhat surprising in light of a previous study reporting no significant differences in the potency of this alkaloid to displace GABA from various human brain regions (Enna et al., 1979). A possible explanation for this discrepancy is that, in the present study, the entire cerebral cortex, midbrain, and cerebellum were utilized for assay, whereas in the human study, only select areas of these brain regions were examined. On the other hand, the differences may be related primarily to the differ-

\section{TABLE V}

Effect of $50 \mathrm{mM}$ ammonium thiocyanate on the potency of GABA to activate specific $\left[{ }^{3} H\right]$ diazepam binding in rat brain cerebral cortex and cerebellum

The concentration of GABA necessary to yield a half-maximal enhancement of $\left[{ }^{3} \mathrm{H}\right]$ diazepam binding $\left(\mathrm{EC}_{50}\right)$ was determined in membranes derived from rat brain cerebral cortex and cerebellum in the presence and absence of ammonium thiocyanate (SCN). Values are the means \pm SEM of four or five separate determinations, each performed in triplicate.

\begin{tabular}{lcc}
\hline \multirow{2}{*}{ Brain Region } & \multicolumn{3}{c}{$\mathrm{EC}_{50}$} \\
\cline { 2 - 3 } & \multicolumn{1}{c}{$+\mathrm{SCN}$} & $+\mathrm{SCN}$ \\
\hline & & $\mu \mathrm{M}$ \\
Cerebral cortex & $0.66 \pm 0.09$ & $0.63 \pm 0.08$ \\
Cerebellum & $0.36 \pm 0.14$ & $0.32 \pm 0.14$ \\
\hline
\end{tabular}

ences in the species examined. In any event, the present findings suggest that the GABA receptor affinity for bicuculline differs among certain rat brain regions, suggesting the presence of pharmacologically distinct GABA receptor subtypes. Such a conclusion would be in accord with previous data indicating a greater amount of $\left[{ }^{3} \mathrm{H}\right]$ bicuculline binding in rat cerebral cortex than in cerebellum (Möhler and Okada, 1977). Although the opposite is true for GABA receptor binding (Enna and Snyder, 1975), electrophysiological studies have suggested the existence of GABA receptors that are less sensitive to bicuculline (Curtis and Felix, 1971; Krnjevic, 1974).

Further evidence for multiple GABA binding sites was provided by the results obtained using ammonium thiocyanate, a chaotropic agent. Previous studies have indicated that, using tissue not previously treated with Triton $\mathrm{X}-100$, the ammonium or sodium salts of thiocyanate, iodide, and nitrate increase the potency of bicuculline to displace membrane-bound $\left[{ }^{3} \mathrm{H}\right] \mathrm{GABA}$ without appreciably altering the affinity of GABA for the receptor site (Enna and Snyder, 1977). In the present study, it was found that a similar effect can be observed in Tritontreated tissue and the finding that the degree of enhancement in the potency of bicuculline differs among the brain regions examined supports the contention that there are fundamental differences in the physiocochemical properties of GABA receptors.

Since chaotropic agents like thiocyanate are useful for solubilizing particulate proteins (Hatefi and Hanstein, 1969), it is possible that the shift in the potency of bicuculline may be due to the removal of some endogenous material which modifies the affinity of the receptor for the alkaloid. If this is the case, the differential effect of ammonium thiocyanate in the brain regions examined may be related to the relative concentrations of this endogenous material. Such a contention is supported by the correlation between the potency of bicuculline to inhibit specifically bound $\left[{ }^{3} \mathrm{H}\right] \mathrm{GABA}$ in various brain areas and the magnitude of the shift of these potencies in the presence of ammonium thiocyanate (Table I). That is, in untreated membranes, the affinity would be higher because there may be less endogenous substance in the cortical and midbrain regions. After treatment with ammonium thiocyanate, most, or all, of the substance is removed in those areas having less of the endogenous material, whereas this concentration of thiocyanate is insufficient to rid other tissues, like the corpus striatum and cerebellum, of this material. To test this, the potency of bicuculline to inhibit $\left[{ }^{3} \mathrm{H}\right] \mathrm{GABA}$ binding in cerebullar membranes was tested over a wide range of ammonium thiocyanate concentrations (up to $200 \mathrm{~mm}$ ). The $\mathrm{IC}_{50}$ in the cerebellum appeared to approach that observed in the cerebral cortex when exposed to higher concentrations of salt (data not shown). However, these data were inconclusive because, with increasing concentrations of thiocyanate, the amount of specifically bound $\left[{ }^{3} \mathrm{H}\right] \mathrm{GABA}$ also decreased, making it difficult to obtain consistent and conclusive data. It is unlikely that this hypothetical substance is GABA itself since removal would be expected to significantly affect the $\mathrm{IC}_{50}$ for GABA as well as bicuculline, which is not the case. Nevertheless, the possibility must be considered 
that the apparent differences in GABA receptors with respect to bicuculline may be due to the presence, at or near the GABA receptor, of some thiocyanate-sensitive substance rather than, or in addition to, a fundamental difference in the physicochemical properties of the receptor molecule.

Using GABA-activated benzodiazepine binding as a biochemical measure of GABA receptor function, the present results also indicate that the thiocyanate-induced shift in the potency of bicuculline is functionally significant in that thiocyanate increased the potency of bicuculline to inhibit the GABA receptor-mediated activation of benzodiazepine binding. Even more significant, however, was the finding that ammonium thiocyanate completely abolished the high affinity binding site for GABA, leaving the low affinity site and the GABA-activated benzodiazepine binding unaltered. While the precise reason for this phenomenon is unknown, it would seem most likely that, at this concentration, ammonium thiocyanate is able to solubilize the high affinity site for GABA selectively. It is unclear at this time whether this action and the effect on the potency of bicuculline are related. Nevertheless, this finding directly demonstrates that the high and low affinity binding sites for GABA are functionally different in that the low, but not the high, is linked to the benzodiazepine receptor. Such a conclusion supports the work of others where, using less direct methods, it has been hypothesized that only the low affinity GABA binding site is associated with the benzodiazepine receptor (Palacios et al., 1979; Braestrup et al., 1980).

In conclusion, the present findings point to the existence of pharmacologically and functionally distinct GABA receptors in brain. The discovery that only low affinity GABA receptors are linked to the benzodiazepine binding site lends biochemical support to the autoradiographic evidence that not all GABA receptors are linked to the binding sites for this drug. The discovery that ammonium thiocyanate selectively abolishes high affinity GABA binding may provide new insights with regard to solubilizing this site and may be a useful method for identifying and defining pharmacologically and functionally distinct $\mathrm{GABA}$ receptors in brain.

\section{References}

Bloom, F. E., and L. L. Iversen (1971) Localizing ${ }^{3}$ H-GABA in nerve terminals of rat cerebral cortex by electron microscopic autoradiography. Nature 229: 629-630.

Bowery, N. G., D. R. Hill, A. L. Hudson, A. Doble, D. N. Middlemiss, J. Shaw, and M. Turnbull (1980) (-)-Baclofen decreases neurotransmitter release in the mammalian CNS by an action at a novel GABA receptor. Nature 283: 92-94.

Braestrup, C., M. Nielsen, P. Krogsgaard-Larsen, and E. Falch (1980) Two or more conformations of benzodiazepine receptors depending on GABA receptors and other variables. In Receptors for Neurotransmitters and Peptide Hormones, G. Pepeu, M. J. Kuhar, and S. J. Enna, eds., pp. 301-312, Raven Press, New York.

Curtis, D. R., and D. Felix (1971) The effect of bicuculline upon synaptic inhibition in the cerebral and cerebellar cortices of the cat. Brain Res. 34: 301-321.

Enna, S. J. (1981a) GABA receptors. Trends Pharmacol. Sci. 2: 62-64.

Enna, S. J. (1981b) GABA receptor pharmacology: Functional considerations. Biochem. Pharmacol., in press.

Enna, S. J., and S. H. Snyder (1975) Properties of $\gamma$-aminobutyric acid (GABA) receptor binding in rat brain synaptic membrane fractions. Brain Res. 100: 81-97.

Enna, S. J., and S. H. Snyder (1977) Influences of ions, enzymes and detergents on $\gamma$-aminobutyric acid receptor binding in synaptic membranes of rat brain. Mol. Pharmacol. 13: 442453.

Enna, S. J., J. W. Ferkany, and P. Krogsgaard-Larsen (1979) Pharmacological characteristics of GABA receptors in different brain regions. In GABA-Neurotransmitters, P. Krogsgaard-Larsen, J. Scheel-Kruger, and H. Kofod, eds., pp. 191200, Academic Press, New York.

Hatefi, Y., and W. G. Hanstein (1969) Solubilization of particulate proteins and nonelectrolytes by chaotropic agents. Proc. Natl. Acad. Sci. U. S. A. 62: 1129-1136.

Krnjevic, K. (1974) Chemical nature of synaptic transmission in vertebrates. Physiol. Rev. 54: 418-540.

Maggi, A., J. Satinover, M. Oberdorfer, E. Mann, and S. J. Enna (1980) Phylogenetic characteristics of muscimol-activated benzodiazepine receptor binding. Brain Res. Bull. 5: 167-171.

Möhler, H., and T. Okada (1977) GABA receptor binding with ${ }^{3} \mathrm{H}-(+)$-bicuculline methiodide in rat CNS. Nature 267: 6567.

Palacios, J. M., D. L. Niehoff, and M. J. Kuhar (1979) Ontogeny of GABA and benzodiazepine receptors: Effects of Triton X100, bromide and muscimol. Brain Res. 179: 390-395.

Tallman, J. F., J. W. Thomas, and D. W. Gallagher (1978) GABAergic modulation of benzodiazepine binding site sensitivity. Nature 274: 383-385.

Young, W. S., and M. J. Kuhar (1979) Autoradiographic localization of benzodiazepine receptors in the brains of humans and animals. Nature 280: 393-395. 